\title{
Long-Stay Beds for the Elderly Severely Mentally IIl A discussion paper
}

Many of the illnesses of old age are disabling, but only a minority of patients end up in institutions. The proportion of elderly so placed, about $5 \%$ of the population over 65 in the UK, is lower than that found in other industrialised nations: a situation that probably reflects the effectiveness of geriatric and psychogeriatric services; the continuing strength of family ties; and the unacceptability of the location of most long-stay beds. Elderly people have a terror of long-stay hospital wards, often housed in buildings which served as work-houses during their lifetimes, and a particular fear of the mental hospital.

Of the mental illnesses of late life, dementia is most likely to lead to institutional care. ${ }^{1}$ In a follow-up study of a community sample, a mere 26 patients with dementia spent 313 weeks in hospital and 360 weeks in residential care, while 343 mentally healthy old people spent only 304 weeks in hospital and 180 weeks in a residential home. On average, a patient with dementia could expect to spend 25.8 weeks in an institution, compared with 1.4 weeks for the 'control' person.

Bergmann and others ${ }^{2}$ have shown that patients with dementia who live with their relatives, be they children or spouses, are less likely to enter institutions than those who live alone. Twelve months after referral to a psychogeriatric unit, $72 \%$ of survivors who had lived alone at referral had entered institutions, compared with half of those living with spouses and only $39 \%$ of those living with children. Paradoxically, when frail old people live within families, they are less likely to be either known to Social Services or to be in receipt of domiciliary support than are those who live alone, but there is little evidence, for cases of dementia, that the provision of home help or domiciliary meals support significantly delays institutionalisation. It has, of course, been demonstrated that Augmented Sheltered Housing Schemes, such as the Kinloss Court Scheme started in Southampton, can provide the sort of support that is adequate for the mentally frail, but there is as yet no convincing evidence that intensive personalised community support packages, pioneered by the Personal Social Services Research Unit of the University of Kent and copied in a number of Social Service Departments in other parts of the country, are fully effective for keeping dementia sufferers out of institutions, even though their success with the physically frail elderly is beyond dispute.

\section{Number of beds}

The number of beds needed to support the severely mentally ill is likely to depend upon a number of factors. These will include:

(1) the nature of the mental illnesses present in a given population, and their relative prevalences

(2) the susceptibility of such illnesses to psychiatric treatment
(3) the availability of family support in a district

(4) the mean survival time of those entering the beds provided

(5) the availability of other effective support systems such as augmented Part 2 accommodation. (Sheltered Housing Schemes).

Studies of the prevalence of dementia in old age have consistently shown an increasing prevalence with increasing age (for a recent report see Copeland $e t$ al). ${ }^{3}$ Continuing demographic trends favour an increasing proportion of very old people, and this is likely to result in an increasing proportion, and number, of demented old people. The majority of old people who die suffering from dementia have been shown to suffer from Alzheimer's disease ${ }^{4}$. In extreme old age, the proportion of old people with surviving spouses falls considerably, and growing evidence that senile dementia of Alzheimer type is found predominantly in women, is particularly discouraging, since most women lose their husbands before attaining the age of 80 , when the prevalence of dementia is at its peak.

Christie $^{5}$ and Blessed \& Wilson ${ }^{6}$ demonstrated that the average survival time for old people with dementia admitted to mental hospitals has increased considerably in recent years and Christie \& Train ${ }^{7}$ have further shown that very old women suffering from dementia (aged over 85), and admitted to ESMI beds after preliminary treatment and support as day patients, survive nearly twice as long as those of comparable age and diagnosis admitted directly from home without prior contact with a developed psychogeriatric service. Thus, the notion that the day hospital might provide care until dementia was far advanced, so reducing survival after eventual admission to hospital, appears unfounded. The recent researches of Rossor $e t a^{8}$ indicate that the principal cause of dementia in those aged 80 an above is Type I Alzheimer's disease - a disabling but less life threatening disorder than early onset or Type II disease. Christie \& Wood ${ }^{9}$ have reported that patients with dementia and admitted to hospital for care before their 75th birthday never achieved life spans predicted by actuarial tables, but $24 \%$ of those admitted after the age of $85 \mathrm{did}$ so.

Existing proposals for long-stay bed provision

These were first made by DHSS in 1972 (HM 72/71) and a figure of 2.5 to 3.0 beds per 1,000 population over 65 was proposed as appropriate for the hospital care of demented old people. These figures were endorsed by the Heatlh Advisory Service in The Rising Tide published in 1982, but in that document a small figure was added to accommodate the elderly with severe and unremitting functional psychoses. Previously, it had been assumed with some justification, that affective illness and paraphrenia responded so well to contemporary psychiatric treatment that no provision for therapeutic failures was necessary. However, 
reports on the prognosis for both disorders reveal that a significant minority of cases will not recover (or may relapse permanently after several attacks with good or partial remission) so that some long stay provision is necessary.

\section{Is it possible to set a satisfactory 'norm'}

It is certainly difficult to suggest a norm which is appropriate for all health districts. 3.0 beds per 1,000 is likely to suffice in a district which has a low prevalence of dementia (say, Leicestershire); there is good social cohesion; a generous provision of beds in the private and voluntary sectors; good provision of beds by the LASSD; and an active and well provided geriatric service. But there is growing evidence that the prevalence of dementia varies from one part of the country to another, being particularly high in inner cities. There is indirect evidence for this arising from examination of established psychogeriatric services. Some operate with no waiting lists for ESMI care, while others have 50 patients waiting. The naive view is that services with no waiting lists are the more effective, but until all factors are carefully considered that assumption should not be accepted without question. We need to remember that our ignorance of the prevalence of dementia by locality is greater than our knowledge and that major demographic surveys of this disorder, which would involve screening of thousands of elderly respondants rather than hundreds, have yet to be carried out in the UK (though Copeland has been recently funded by the MRC to do so).

\section{A suggested provision}

(1) Where prevalences of dementia are known (London Liverpool, Crewe, Newcastle, Leicestershire) provision might be made on the basis of 1 bed per 1,000 for each $1 \%$ of prevalence.*

(2) Where prevalences are not known, provision might be made on the basis of 3.0 beds per 1,000 as a base line, that should be increased, where: (a) geriatric provision falls below 10 beds per 1,000 ; (b) residential beds fell below 25 beds per 1,000; and (c) where there are more than 25 patients on the ESMI waiting list. The increase might be by one or two beds per 1,000 , with review after five years. Contrary to cynical predictions of waiting lists rigging, I believe that most psychogeriatricians - who would have to look after the extra beds anyway-would not seek to increase their 'empires' unless forced to do so.

(3) Districts should of course look at acute bed provision and day treatment provision in relation to long-stay beds, and offer improved assessment and treatment facilities in preference to long-stay beds where this is appropriate (e.g. if provision of acute beds or day facilities falls significantly below 'Rising Tide' norms).

* This is considerably smaller than the planned provision of dementia beds for Scotland of 10 beds per 1,000 over $65 .^{10}$

\section{Location of long-stay beds}

Continued location of ESMI beds in mental hospitals removes choice from caring relatives. I could not foresee myself being willing to allow my wife to go into a mental hospital for ESMI care and I believe this to be a fairly common sentiment. Were places provided in homely homes, each accommodating six to 12 residents and staffed by appropriately trained people, or even in buildings akin to homes built for LASSD Part III provision, then relatives would be more likely to avail themselves of ESMI care, and I believe that they are entitled to that choice.

\section{Possible use of the private sector}

I have personal knowledge of excellent private nursing homes, run by former NHS nursing staff, which provide high quality support for severely mentally ill residents, far more acceptable to relatives than mental hospital back ward care. Current DHSS ceilings on board and lodging allowances operate against the developments of such specialised homes, for, even in the North East of England, the break-even point for a newly developed and appropriately staffed home is about $£ 200.00$ per week (1987 prices), $£ 20.00$ more than the ceiling allowance $£ 180.00$ and pocket money. Few relatives are able and willing to pay a subsidy, so that assessed patients have to wait for hospital care in expensive assessment beds.

Authorising an enhanced allowance for patients admitted to nursing homes who have been fully assessed by a psychogeriatric team and recommended for private care might encourage the private sector to provide all or part of the difference between the basic 3.0 beds per 1,000 suggested and the real need, which in some districts will be five or six beds per 1,000 .

University Department of Psychiatry

Brighton Clinic, Newcastle General Hospital

\section{REFERENCES}

${ }^{1}$ Kay, D. W. K., Bergmann, K., Foster, E. M., McKennie, A. A. \& Roth, M. (1970) Mental illness and hospital usage in the elderly: a random sample followed up. Comprehensive Psychiatry, 11, 26

${ }^{2}$ Bergmann, K., Foster, E. M., Justice, A. W. \& Matthews, V. (1978) Management of the demented elderly patient in the community. British Journal of Psychiatry, 132, 441-450.

${ }^{3}$ Copeland, J. R. M., Dewey, M. E., Wood, N., Searle, R., Davidson, I. A. \& MCWilliam, C. (1987) Range of mental illness among the elderly in the community: Prevalence in Liverpool using the GMS-AGECAT package. British Journal of Psychiatry, 150, 815-824.

${ }^{4}$ Tomlinson, B. E. (1979) The structural and quantitative aspects of dementia. In Biochemistry of Dementia. (ed. P. J. Roberts. Chichester: John Wiley. pp 15-52.

${ }^{5}$ CHRISTIE, A. (1982) Changing patterns of mental illness in the elderly. British Journal of Psychiatry, 140,154-159.

${ }^{6}$ Blessed, G. \& WiLson, I. D. (1982) The contemporary national history of mental disorder in old age. British Journal of Psychiatry, 141, 59-67. 
${ }^{7}$ Christie, A. B. \& Train, J. B. (1984) Change in the pattern of care for the demented. British Journal of Psychiatry, 144, 9-15.

${ }^{8}$ Rossor, M. N., IVERSEN, L. L., ReYnolds, G. P., MountJoy, C. Q \& RoTH, M. (1984) Neurochemical characteristics of early and late onset types of Alzheimer's disease. British Medical Journal, 288, 961-964.
${ }^{9}$ Christie, A. B. \& Wood, E. R. M. (1988) Age, clinical features and progress in SDAT. International Journal of Geriatric Psychiatry, 3, 63-68.

${ }^{10}$ Scottish House and Health Department (1980) Scottish Health Authorities Priorities for the Eighties (SHAPE) A report by the Scottish Health Service Planning Council. Edinburgh: HMSO 1980: 31 .

\section{College Research Unit}

Council has recently approved the appointment of Professor John Wing as the first Director of the College's Re- search Unit. Professor Wing will take up this post in 1989.

R. G. PrIEST, Registrar

\section{Obituary}

Editor: Henry R. Rollin

James Christopher Penton, formerly Director, Army Personnel Research Establishment

Dr James Christopher Penton, a Foundation Fellow of the College, died on 18 November 1987 in St Lawrence's Hospital, Bodmin. Earlier in his career he had been Assistant Director of Army Psychiatry and, after returning to civilian life, Head of the Psychology Section at the Army Operational Research Group in West Byfleet and later Director of the Army Personnel Research Establishment at the Royal Aircraft Establishment in Farnborough.

Christopher Penton was born in 1910 and, after school at Repton, he went up to New College, Oxford in 1928 and later to the Middlesex Hospital. He took an Honours degree in Physiology and graduated BA, BM, BCh (Oxford) in 1935 and MA in 1963. After house jobs in the East London Children's Hospital and at Queen Mary's Hospital, Stratford, he specialised in psychiatry, returning to Oxford as assistant medical officer at Littlemore Mental Hospital. He took the DPM in 1940 and joined the Royal MedicoPsychological Association in January 1941. From 1942 to 1948 he served in the RAMC and rose to the rank of Lieutenant-Colonel and Assistant Director of Army Psychiatry. After returning to civilian life, he continued his work for the War Office, first as Head of the Psychology Section of the Army Operational Research Group at West Byfleet (from 1948 until 1963) and later (from 1964 until 1971) as Director of the Army Personnel Research Establishment at the Royal Aircraft Establishment in Farnborough, Hants. During all this time he played an important part in developing the techniques of personnel selection, particularly those used in choosing candidates for officer training. After he retired from that job he went to live in Cornwall where he returned to clinical work as Assistant
Psychiatrist at St Lawrence's Hospital, Bodmin from 1972 to 1975.

Christopher Penton will be remembered by his friends, not only for his colourful personality, but as among the most courteous, kind, civilised and cultured of men. He carried with him something of his Oxford background throughout his life. Among his many and varied interests was a keen love of music. He was an accomplished pianist and he could be often seen at performances of Handel's operas by the Handel Opera Society in Sadler's Wells. He was also an enthusiastic and knowledgeable Wagnerite, a combination which shows something of the range and catholicity of his musical tastes. He was an excellent host and an outstanding cook and gardener. He was also a keen folk dancer, and the strength of his personality and powers of persuasion are well exemplified by his success in organising regular lunch-time sessions of country dancing for the War Office personnel in West Byfleet when he served there. Later in life he established a group of Morris Dancers in Cornwall and remained an active member into old age.

He was a regular attender at the yearly meetings of the British Association for the Advancement of Science (always affectionately referred to by him as "The British Ass") and was also an Associate of the British Psychological Society.

Christopher married late at the age of 42 , Nancy E. Ewart, a gifted artist. They had a very happy life together which was cruelly cut short by her illness and early death. Christopher will be remembered with affection by his friends, not only for his unique personality and wideranging interests, but for his innate kindness. His life-long interest in social and community psychiatry continued after he retired from his work for the War Office (by then the Ministry of Defence) in his clinical work at St Lawrence's Hospital in Cornwall. 